The survival of transplanted coral on pyramid-shaped ... (Ofri Johan)

\title{
THE SURVIVAL OF TRANSPLANTED CORAL ON PYRAMID- SHAPED FISH SHELTER ON THE COASTAL WATERS OF KELAPA AND HARAPAN ISLANDS, KEPULAUAN SERIBU, JAKARTA
}

\author{
Ofri Johan\# \\ Center for Aquaculture Research and Development, J akarta
}

(Received 22 March 2012 ; Accepted 12 May 2012)

\begin{abstract}
Research was carried out in August 2008 at two sites within Marine Protected Areas (MPA) in Kelapa and Harapan Islands of Seribu Islands, Indonesia. The purpose of this research was to compare the mortality rate of coral transplanted on the upper and base of pyramid-shaped concrete fish shelters. Fish shelters were placed on the seabed of Kelapa Island which is characterized by sandy seabed and Harapan Island which is characterized by silt. Both sites are within Marine Protected Areas. The survey recorded mortality rate of transplanted coral and percentage of live coral coverage. The research also sampled fish populations within the MPA sites and pyramid areas so that the two sites can be compared for their fish biodiversity. The data were analyzed by using T- Test Student of SPSS 11.5 computer program to compare between two locations, and upper and base of transplanted position. After one year, the average mortality rate among transplanted coral species in Kelapa Island was 34\% However, the mortality rate of transplanted coral in Harapan Island was slightly higher than in Kelapa Island: $42 \%$ The transplanted coral at the top of the fish shelter had higher survival rate $(39 \%)$ compared to the base of the fish shelter $(24 \%$ ). Fish populations in Kelapa Island consisted of 1,119 individuals from 35 species. This was much higher than in Harapan Island where the research found only 655 individuals from 27 species. Fish populations found around the fish shelter area in Kelapa Island consisted of 125 individuals from 25 species. This was lower than the fish population in Harapan Island, where 206 individuals from 23 species were recorded.
\end{abstract}

KEYWORDS: fish shelter, coral transplantation, pyramid shape, mortality, Seribu Islands

\section{INTRODUCTION}

Fish shelters, artificial reefs and fish aggregating devices may be able to increase fish populations by mimicking natural habitats (Solarin, 2004). Functions of artificial reefs include: beach protection from erosion, mitigation from the impact of habitat destruction, biodiversity conservation, providing habitats of marine biota, providing nursery grounds for marine biota, providing study sites to study ecological theory and underwater ecotourism. Several years ago, pedicabs and damaged cars have been dumped in several locations to develop artificial reefs. Another type of artificial reef uses pyramid-shaped substrate to attract fish. The factors that constitute a good type of artificial reef in terms of its applicabil-

\# Corresponding author. Center for Aquaculture Research and Development JI. Ragunan 20, Pasar Minggu, Jakarta Selatan 12540, Indonesia. Tel.: +62 217805052 E-mail address: ofrijohan@cria.indosat.net.id 
ity for coastal community to use are construction stability, good design and economic cost (Haris \& Rani, 1992; Baine, 2001; Seaman \& Jensen, 2000). Beside the pyramid shape, there are other several shapes used for fish shelters such as cube, mosque dome and reef ball. These various fish shelters are used in several locations in coastal waters off Seribu Islands.

Transplanting coral on to fish shelters is a new idea and the first time it has been applied. Coral fragments are placed on the fish shelter by fixing them in the rectangular holes of the base and the upper part of fish shelter. Regular monitoring is necessary to check the success of transplantation and to evaluate the changes in fish populations.

\section{MATERIALS AND METHODS}

The research was conducted at two locations: Kelapa and Harapan Islands, Seribu Islands, Jakarta in August 2008.

The survival of transplanted coral was evaluated visually underwater using SQUBA equipment. to record survived and dead coral as well as to measure the The size of transplanted corals length was measured using callipers, and the status (live/ dead) of each transplanted coral was recorded. Pictures of transplanted coral were captured using underwater camera Olympus Z- 5060 for documentation purpose.

Observations of fish abundance were carried out on both fish shelter and marine protected areas (MPA) using underwater visual survey methods of long line intercept transect $(3 \times 50 \mathrm{~m})$ in the MPA and timed swimming method in the fish shelter area.

The number of fish recorded in Harapan and Kelapa Island sites were 61 and 65 individuals respectively. In each location there were 8 transplanted corals with 4 transplanted on the upper part and 4 transplanted on the base part of the fish shelter. The dimensions of the fish shelter are: base $60 \times 60 \mathrm{~cm}$, top $20 \times 20 \mathrm{~cm}$ and height $40 \mathrm{~cm}$ (Figure 1).

The location of the fish shelters in the MPA at Kelapa Island is a protected area established by the local community. Fish shelters were placed on a rubble and sandy area to minimize any potential effect on the nearby reef. The fish shelters were positioned perpendicular to the coastal line at $4 \mathrm{~m}$ depth so that monitoring

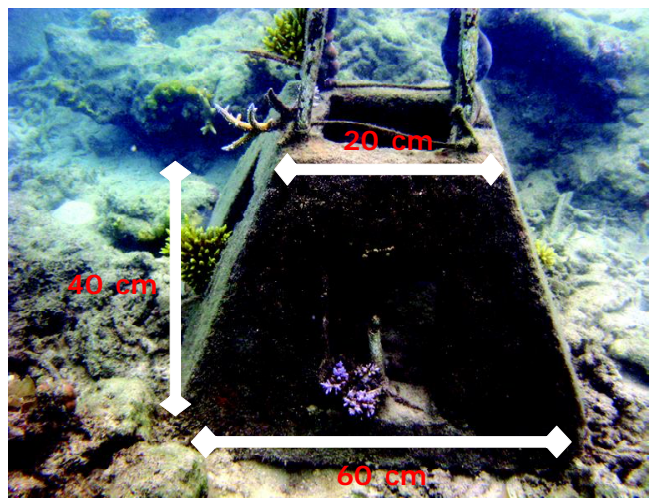

Figure 1. Fish shelter and transplanted coral after 1 year

activities could be easily undertaken. The bottom substrate consists of sand and silt and as a result water visibility is variable. During periods of high waves and strong current, the water becomes turbid.

Survival data of colonies number at the base and upper part of the fish shelter was analysed to get a difference of transplanted position on the fish shelter and transplanted sites by using T-Test student of SPSS 11.5 computer program.

\section{RESULT AND DISCUSSION}

\section{Kelapa Island Marine Protected Area (MPA)}

The observation of coral condition by using LIT (line intercept transect) method found $37.7 \%$ life coral cover. Coverage for other coral types was: soft coral $2.6 \%$ sand $7.5 \%$ rubble $12.1 \%$ and rock $6.0 \%$ This coral condition is classified as poor condition, i.e. between $25 \%$ and $50 \%$

The observations on transplanted coral on 65 fish shelters indicated that the coral mortality rate on the upper part of the fish shelters (61.4\%) was less than that of the base of pyramid (76.4\% (Figure 2).

The total number of transplanted coral colonies surviving at the upper part of the fish shelters was 68 colonies, while on the base of the fish shelter only 31 colonies survived from an initial 260 transplanted colonies, this is significant different according to T-Test student. In general, survival was better for colonies on the upper part of the fish shelters, and lower 
The survival of transplanted coral on pyramid-shaped ... (Ofri Johan)

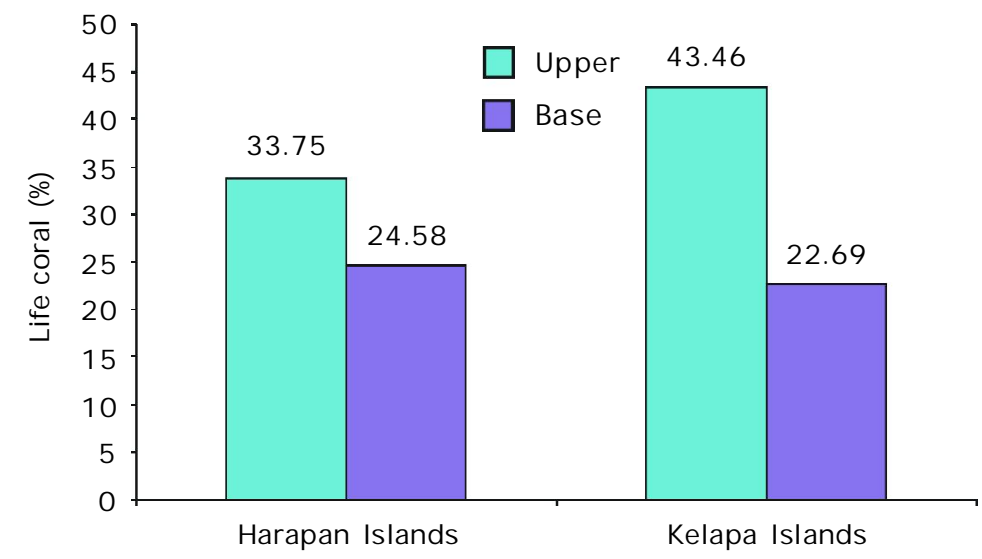

Figure 2. Percentage of live coral on the upper and the base parts of pyramid fish shelters at Harapan and Kelapa Island, Seribu Islands

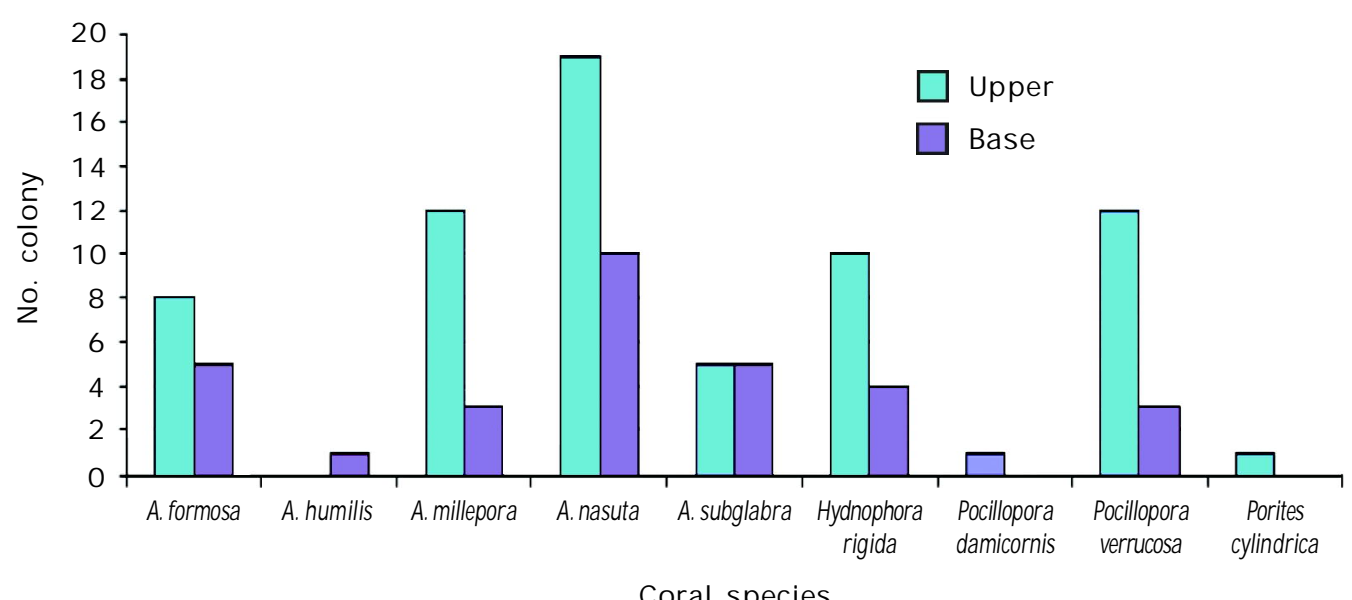

Figure 3. The number of surviving colonies of each coral species from 65 fish shelters at Kelapa Island

for colonies on the base (Figure 3). Among the coral species transplanted, Acropora nasuta had a higher survival rate than other coral species (Figure 3 and Table 1).

This results suggest that transplanted coral higher on the fish shelters survives better than coral transplanted on the lower parts of the shelters. The coral on the upper part is free from the effects of sedimentation and benefits from optimal sunlight penetration. This finding is in line with opinions of experts who suggest that an increase in suspended sediment will degrade live coral coverage (Morelock et al., 1983; Rogers, 1990).
The observations of fish on the MPA site found 1,119 individuals from 35 species, while at the location of fish shelters 125 fish from 25 species were found (Table 1 ).

\section{Harapan Island MPA}

Based on the LIT data, the live coral cover in Harapan Island was $38.3 \%$ which is classified as 'damaged'. In addition, is the survey found that dead coral coverage, algae, other fauna, and abiotic was $0.75 \% 0.3 \% 65 \%$ and $60 \%$ respectively. Abiotic was dominated by coral rubble $(44.1 \%$, sand $10.5 \%$ and rock $5.4 \%$ This coral condition was not different from that 
recorded at the Kelapa Island MPA site. The only difference was the amount of coral rubble cover and sand which was higher at Harapan Island, and also the coral cover of Acropora was less (only $0.2 \%$, compared with $18.25 \%$ at Kelapa Island. This data suggests that the Acropora is not suitable for this sandy substrate area.

There were 61 fish shelters observed where the average survival rates of transplanted coral on the upper part was 81 (34\%) and on the base was 59 colonies ( $25 \%$ from 240 total initial colonies for each treatment (Table 1). Table 1 suggests that corals belonging to the genus Pocillopora (20 colonies) in Harapan Island had a higher survival rate than that of corals belonging to the genus Acropora (17 colonies) or other species, but it is not statistically different. While the corals belonging to genus Acropora sp. (58 colonies) in Kelapa had a higher survival rate than that of corals belonging to genus Pocilloporidae (16 colonies), no statistically different. This reflects the general view that corals from the Family Pocilliporidae are regarded as pioneers in coral reefs due to their high survival rate and adaptation ability in marine environments (Endean \& Cameron, 1990).

Fish abundance data showed that the number of fish was lower (655 individuals) at Harapan Island MPA than at Kelapa Island (1119 individuals). The number of fish around the fish shelter area in Harapan Island was 206 indi- viduals, which was higher than at Kelapa Island (125 individual) (Table 2). This result shows that after one year of fish shelter establishment, there is a positive impact on fish abundance in this location. According to the data, the coral condition at Kelapa Island MPA has a high percentage of live coral cover from Acropora corals and good substrate which has lower sand and silt percentages, providing a better habitat and greater fish abundance.

Observation of the fish shelters showed that the surface was encrusted by turf algae, macroalgae, ascidians, sponges and soft corals. No hard corals were found on the fish shelter surfaces.

It is expected that these fish shelters can serve as new fishing areas. However, to conserve fish numbers it is essential to limit fishing activities and use fishing gears which do not damage the habitat. One alternative to conserve natural coral reefs is to use artificial reefs as fishing sites.

If artificial reefs are designed and established properly, the ecosystem can benefit through: (1) increased topographic complexity, (2) provision of a stable substrate for new recruitment coral or transplanted coral, (3) aggregation of fish, (4) beach protection, (5) the structures can eliminate the potential damage caused by nets on coral reef areas, and (6) provision of alternative diving sites to alleviate pressure on natural coral reefs.

Table 1. Survival and number of colonies of transplanted coral species at the Harapan Island site

\begin{tabular}{lcc}
\hline \multicolumn{1}{c}{ Species } & Harapan Island & Kelapa Island \\
\hline A. millepora & 5 & 15 \\
A. subglabra & 2 & 10 \\
A. formosa & 0 & 13 \\
A. humilis & 0 & 1 \\
A. nasuta & 0 & 29 \\
Acropora sp. & 10 & 0 \\
Hydnophora rigida & 7 & 14 \\
Pocillopora damicornis & 7 & 1 \\
Pocillopora verrucosa & 13 & 15 \\
Porites cylindrica & 0 & 1 \\
Stylophora sp. & 4 & 0 \\
\hline \multicolumn{1}{c}{ Total } & $\mathbf{4 8}$ & $\mathbf{9 9}$ \\
\hline
\end{tabular}


The survival of transplanted coral on pyramid-shaped ... (Ofri Johan)

Table 2. Individual number of fish in marine protected area (MPA) and fish shelter sites of Harapan and Kelapa Island

\begin{tabular}{|c|c|c|c|c|c|}
\hline \multirow{2}{*}{ Family } & \multirow{2}{*}{ Species } & \multicolumn{2}{|c|}{ Fish shelter } & \multicolumn{2}{|c|}{ MPA } \\
\hline & & Harapan & Kelapa & Harapan & Kelapa \\
\hline \multirow[t]{4}{*}{ Apogonidae } & Apogon compressus & 11 & & & 75 \\
\hline & Cheilodipterus artus & & & & 8 \\
\hline & Apogon fuscus & & & & 2 \\
\hline & Apogon apogonides & & & & 12 \\
\hline Belonidae & Tylosurus crocodilus & & & 46 & \\
\hline Caesionidae & Caesio cuning & & & 31 & 96 \\
\hline \multirow[t]{3}{*}{ Chaetodontidae } & Chaetodon oct ofasciatus & 3 & 6 & 27 & 26 \\
\hline & Chelmon rostratus & & & 2 & \\
\hline & Heniochus varius & & & & 1 \\
\hline Gobiidae & Istigobius decoratus & & & & 2 \\
\hline \multirow[t]{8}{*}{ Labridae } & Labroides dimidiatus & 2 & 2 & 2 & 2 \\
\hline & Bodianus mesothorax & 3 & & & \\
\hline & Thalassoma lunare & 5 & 6 & 3 & 29 \\
\hline & Halichoeres leucurus & 7 & & 2 & 2 \\
\hline & Halichoeres dussumieri & 2 & 2 & 3 & 1 \\
\hline & Halichoeres biocellatus & 3 & 3 & 10 & \\
\hline & Halichoeres marginatus & 3 & 3 & 5 & 3 \\
\hline & Choerodon fasciatus & & & 6 & 6 \\
\hline Lutjanidae & Lutjanus biguttatus & & 1 & 1 & \\
\hline \multirow[t]{4}{*}{ Nemipteridae } & Scolopsis auratus & 1 & 3 & 1 & \\
\hline & Pentapodus caninus & 4 & 1 & & 2 \\
\hline & Scolopsis lineatus & & 2 & & \\
\hline & Cirrhilabrus cyanopleura & & & 30 & 45 \\
\hline \multirow[t]{15}{*}{ Pomac anthidae } & Chaetodontoplus mesoleucus & 2 & & 10 & 4 \\
\hline & Abudefduf septemfasciatus & 8 & 2 & & \\
\hline & Abudefduf sexfasciatus & & 2 & & \\
\hline & Halichoeres biocellatus & & & & 8 \\
\hline & Amblyglyphidodon curacao & 28 & 12 & 63 & 123 \\
\hline & Amblyglyphidodon batunai & & & 40 & 46 \\
\hline & Neoglyphidodon melas & 3 & & 27 & 30 \\
\hline & Neoglyphidodon crossi & & 11 & 18 & 23 \\
\hline & N. thoracotaeniatus & & & & 43 \\
\hline & Pomacentrus alexanderae & 40 & 13 & 212 & 160 \\
\hline & Chromis atripectoralis & 18 & & & \\
\hline & Chrom is viridis & & 13 & & 29 \\
\hline & Chrom is atripectoralis & & & 43 & 72 \\
\hline & Chromis xanthochira & & & & 114 \\
\hline & Dischistodus perspicillatus & 28 & & & \\
\hline
\end{tabular}


Indonesian Aquaculture Journal Vol.7 No.1, 2012

Table 2 continued

\begin{tabular}{|c|c|c|c|c|c|}
\hline \multirow{2}{*}{ Family } & \multirow{2}{*}{ Species } & \multicolumn{2}{|c|}{ Fish shelter } & \multicolumn{2}{|c|}{ MPA } \\
\hline & & Harapan & Kelapa & Harapan & Kelapa \\
\hline & Dischistodus prosopotaenia & 2 & 1 & 8 & \\
\hline & Pomacentrus amboinensis & 6 & & & 26 \\
\hline & Pomacentrus moluccensis & & & 8 & 56 \\
\hline & Pomacentrus milleri & 8 & 12 & & 54 \\
\hline & Pomacentrus coelest is & & & 1 & \\
\hline & Stegastes nigricans & 18 & 1 & & 13 \\
\hline & Abudefduf septemfasciatus & & & & 1 \\
\hline & Amphiprion melanopus & & & & 2 \\
\hline \multirow[t]{5}{*}{ Scaridae } & Siganus vulpinus & & 3 & & \\
\hline & Scarus oviceps & 1 & 3 & & \\
\hline & Chlorurus sordidus & & 3 & 18 & 2 \\
\hline & Scarus globiceps & & 2 & 36 & \\
\hline & Scarus rivulatus & & 17 & & \\
\hline \multirow[t]{2}{*}{ Serranidae } & Epinephelus amblycephalus & & 1 & & 1 \\
\hline & Cephalopolis boenack & & & 2 & \\
\hline \multirow[t]{3}{*}{ Siganidae } & Amphiprion sandaracinos & & & & \\
\hline & Total individuals & 206 & 125 & 655 & 1,119 \\
\hline & Total species & 23 & 25 & 27 & 35 \\
\hline
\end{tabular}

Artificial reefs can be based on various designs, but different designs provide similar functions and benefits to surrounding habitats. Two of the design forms are dome shape and concrete cement placed in shallow water (depth 5- $10 \mathrm{~m}$ ) and close to natural coral reefs. This approach will allow more rapid recruitment of new corals, whereas artificial reefs placed at a depth of more than $15 \mathrm{~m}$ and far from natural coral reefs recruit less coral larvae. However, these deeper artificial reefs can still serve as fish aggregation devices.

The dome shaped structures used for artificial reefs attract more coral larvae compared with pipe shaped structures because they have a wider surface per square meter which provides more opportunity for encrusting with new coral larvae. According to the survey by Munasik (2008), abundance of newly recruited coral colonies on dome- shaped artificial reef structures can reach 70 colonies per unit with diameter ranging from 1 and $40 \mathrm{~cm}$ after 4 years placement. The coral species which are encrusted on artificial reefs are mainly the pio- neer species found on natural coral reefs, especially from the Family Pocilloporidae.

In addition to high fish abundance, the fish shelter areas also hosts more than 9 species of hard corals. Coral abundance encrusted on dome artificial reefs shapes on Menjangan Besar Island, Karimunjawa Island after 4 years reached 44 colonies/ unit (Munasik, 2008).

\section{CONCLUSION}

The upper part of the pyramid- shaped fish shelter is more successful in supporting the survival of transplanted corals compared to the base of the pyramid. Abundance of individuals and species of reef fish is a good sign of the positive impact of the existence of fish shelter after 1 year establishment. The data also showed that the coral $A$. nasuta has higher survival rate in Kelapa Island and coral Pocillopora sp. was the best survivor in Harapan Island, but it is not significant different statistically. Coral condition and abundance of fish are higher in MPA than on fish shelter area on both Harapan and Kelapa Island. 


\section{ACKNOWLEDGEMENTS}

The author would like to thank Alimuddin and Dondi for their assistance and help in data collection in the field. Many thanks also attributed to the Local Fisheries Officers who invited me in monitoring of coral condition of Seribu Islands.

\section{REFERENCES}

Solaris, B.B. 2004. Sheltering the fish. Samudra March 2004, p. 3- 5.

Baine, M. 2001. Artificial reefs: a review of their design, application, management and performance. Ocean \& Coastal Management, 44: 241- 259.

Crabbe, M.J.C. \&Smith, D.J. 2005. Sediment impacts on growth rates of Acropora and Porites corals from fringing reefs of Sulawesi, Indonesia. Coral Reef, 24: 437441.

Endean, R. \& Cameron, A. M. 1990. Trends and new perspective in coral- reef ecology, In. Dubinsky, Z. (Ed.): Ecosystem of the world Vol. 25, Coral Reefs, p. 469-492. Elsevier, Amsterdam.
Fabricius et al. 2007. Selective mortality in coastal reef organisms from a acute sedimentation event. Coral Reefs, 26: 69.

Haris, A. \& Rani, C. 1992. Pembuatan Terumbu Karang Buatan di Perairan Pantai Pulau Barrang Lompo Kotamadya Ujung Pandang. Laporan Penelitian. Fakultas Peternakan dan Perikanan Unhas. Ujung Pandang.

Morelock, J., Grove, K., \&Hernández, M.L. 1983. Oceanography and patterns of shelf sediments Mayagüez, Puerto Rico. J. Sed. Petrol., 53: 31- 381.

Munasik. 2008. Kondisi terumbu buatan berbahan beton pada beberapa perairan di Indonesia. Prosiding Musyawarah Nasional Terumbu Kar ang II, Jakarta.

Rogers, C.S. 1990. Responses of coral reefs and reef organisms to sedimentation. Mar. Ecol. Prog. Ser., 62: 185- 202.

Seaman, W., \&Jensen, A.C. 2000. Purposes and practices of articial reef evaluation. In Seaman, W. (Ed.), Articial reef evaluation with application to natural marine habitats (p. 2- 19). Boca Raton, FL: CRC Press LLC. 